\title{
Teologia e cultura: \\ tensões em tempos pandêmicos II
}

\author{
Odenicio Junior Marques de Melo*
}

\begin{abstract}
RESUMO
O presente artigo tem por objetivo propor uma reflexão, em continuidade ao texto publicado no v. 19, n. 2 (2020) dessa mesma revista, sobre a teologia e cultura no pensamento de Tillich como recursos de interpretação da espiritualidade, ou sobre a dor espiritual no contexto da pandemia. A reflexão encontra-se dividida em duas partes: na primeira, será feita uma correlação entre o contexto teológico-filosófico na peste bubônica no século XIV, onde vamos tentar visualizar algumas situações em comum entre aquele período e o que enfrentamos hoje com a covid-19. Na segunda, serão abordados os cuidados com a dor espiritual, tanto na dimensão coletiva, quanto na dimensão individual, a partir da teologia de Tillich, tentando entender as questões do ser como ponto de partida para a pergunta sobre Deus em situações limite.
\end{abstract}

\section{THEOLOGY AND CULTURE: TENSIONS IN PANDEMIC TIMES II}

\begin{abstract}
Continuing the paper published in Correlatio's v. 19, no. 2 (2020), this paper proposes a reflection on theology and culture in Tillich's thought as resources for interpreting spirituality or on spiritual pain in the context of the pandemic. The paper is divided into two main parts: first, a correlation between the theological-philosophical context in bubonic plague in the 14th century is made; where we will try to visualize some common situations between that period and what we face today with the covid- 19. Second, individual and social spiritual pain will be addressed
\end{abstract}

* Graduado em Teologia pela Escola Superior de Teologia - RS, Mestre em Educação Arte e História da Cultura no PPG-EAHC Universidade Presbiteriana Mackenzie - SP, Mestrando em Filosofia pelo PPGFIL-UERJ - RJ. E-mail: odeniciojunior@hotmail. com- http://lattes.cnpq.br/6423504247664050

https://orcid.org/0000-0002-1706-2019 
based on Tillich's theology, trying to understand the problems of being as a starting point for the question about God in extreme situations.

Keywords: Theology - Culture - Spiritual Pain - Care

\section{Introdução}

Inicio a presente discussão relatando uma imagem que certamente será ponto de partida para inúmeras reflexões teológicas e filosóficas. Cheguei para as visitas do dia no centro de terapia intensiva, e uma notícia boa, uma paciente seria extubada, ou seja, sairia da respiração artificial, pois estava evoluindo bem em seu tratamento. Equipe animada, sempre que ocorria alguma melhora significativa e que os riscos diminuíam, e os olhares entre os profissionais eram tomados de enorme alegria. Cada vida representa muito. No entanto, no leito ao lado, bem no momento do plantão em que experimentávamos aquela alegria de uma paciente evoluindo bem, uma intercorrência no leito ao lado, uma parada cardiorrespiratória de outro paciente, jovem. Uma mistura de percepções de mundo, um sentimento de impotência, tanto no plano coletivo quanto no individual.

O presente artigo tem por objetivo propor uma reflexão, em continuidade ao texto publicado no v. 19, n. 2 (2020) dessa mesma revista, sobre a teologia e cultura no pensamento de Tillich como recursos de interpretação da espiritualidade, ou sobre a dor espiritual no contexto da pandemia.

A reflexão encontra-se dividida em duas partes: na primeira, será feita uma correlação entre o contexto teológico-filosófico na peste bubônica no século XIV, onde vamos tentar visualizar algumas situações em comum entre aquele período e o que enfrentamos hoje com a covid-19. Na segunda, serão abordados os cuidados com a dor espiritual, tanto na dimensão coletiva, quanto na dimensão individual, a partir da teologia de Tillich, tentando entender as questões do ser como ponto de partida para a pergunta sobre Deus em situações limite.

\section{Reconfigurações teológicas no período da peste bubônica (Século XIV) \\ Olhar para a história em busca de respostas para o presente é um exercício saudável. Diante do atual contexto da pandemia da covid-19, e os questionamentos existenciais que têm surgido diante da situação}


delicada que atravessamos como coabitantes da Terra, nessa parte do artigo, tentarei sinalizar alguns aspectos teológicos em um período de igual forma difícil para a humanidade, especialmente na Europa, que foi o epicentro da peste bubônica.

Os antecedentes da peste no século XIV remontam a um cenário apocalíptico, "em torno de 1320, quase toda a Europa setentrional estava sofrendo uma fome coletiva de ampla difusão, precipitada por uma série de quebras de safra que se deveram às condições extremamente anormais de mau tempo (LINDBERG, 2001, p. 40).” Há um episódio que data possivelmente de 1315 ou 1317, com o imperador Carlos IV,

Despertado uma manhã por um cavaleiro, que teria lhe dito as seguintes palavras: 'Levanta-te, senhor! O Juízo Final está aqui, pois o mundo inteiro está cheio de gafanhotos.' Carlos saiu montado a cavalo para medir a extensão dos enxames. Após um dia inteiro de cavalgada, de cerca de 25 quilômetros, ele ainda não tinha chegado ao fim do enxame, que devorava toda a vegetação encontrada em seu caminho (BOOOCKMAN (1987) apud LINDBERG, 2001, p. 41).

A situação gerava medo, e as pessoas apelavam para a religiosidade, pois era corriqueiro pensar que tamanha crise tinha uma causa no mundo espiritual, como se Deus estivesse irado, e as consequências dessa ira podiam ser vistas no meio do caos experimentado no Velho Mundo nesse período.

Somada a essa escassez de alimentos, entre 1347 e 1348 começa a se alastrar pela Europa uma doença que viria a ceifar a vida de 1/3 da população.

A natureza terrível dessa doença aumentava seu horror: furúnculos grandes e dolorosos; o termo 'bubônica' vem de buba, palavra latina que designa a virilha, local em que os gânglios linfáticos eram frequentemente os primeiros a inchar, já que muitas mordidas de pulga ocorriam nas pernas, acompanhados por manchas ou pústulas negras em decorrência do sangramento sob a pele, eram o prelúdio para o estágio final de violentas tossidelas de puro sangue (LINDBERG, 2001, p. 41).

Em decorrência do horror causado pela doença, inicia-se um processo de quebra de representações simbólicas. Pois havia algum 
tipo de estabilidade na maneira teológica e filosófica como se pensava as grandes questões da existência naquele período.

A Teologia e a Filosofia na idade média tardia eram muito profícuas em suas discussões. Hoje se sabe que o antigo modo de se referir à Idade Média como Idade das Trevas não cabe mais. E prevalecia a imagem de um mundo até então, guiado por Deus, onde a Igreja representava o divino na terra, e diante de Deus, representava o povo. Era uma espiritualidade com certo grau de estabilidade, onde os religiosos tentavam ter o controle sobre o cotidiano da vida comum.

Do mesmo modo que, em nossos dias, a reflexão do filósofo não pode deixar de se exercer sobre os resultados mais gerais das ciências históricas e sociais, na Idade Média ela dificilmente pode se exercer sobre outra coisa que a revelação, de que o dogma é a expressão definitiva. $\mathrm{O}$ mundo imediatamente dado, como é hoje, o da ciência para nós, é, então o mundo da fé. A realidade é, pois, nessa época, diretamente sentida e pensada como religiosa (GILSON, 1995, p. 942).

Participar do mundo nessa época tinha a ver com um olhar mediado pelo que os dogmas diziam. E diante dos acontecimentos catastróficos do período essa estabilidade vai ruindo. As certezas vão dando lugar aos questionamentos. É importante investigar algumas características dessa estrutura eclesiástica como pano de fundo cultural, antes de avançarmos para os desdobramentos desse período delicado.

Estamos falando dos períodos posteriores às construções góticas, após o que Justo Gonzáles (2011, p. 435) reconhece como o ápice do papado. Onde o pensamento teológico e filosófico era impulsionado pelas discussões entre o nominalismo e realismo, um dos grandes períodos da história intelectual.

Vimos aqui uma das características profundas da sociedade e da civilização medievais, que é uma tensão entre relações diretas e relações indiretas com Deus. Nesse domínio evidentemente, a Igreja é ator fundamental. Por sua vontade de dominação e, de resto, seu sucesso, ela se esforça para funcionar de modo permanente como um intermediário obrigatório entre o homem e Deus. Os principais instrumentos da dominação da Igreja foram a consolidação da teologia e a prática dos sacramentos (LE GOFF, 2010, p. 88). 
Com os acontecimentos nos idos do século XIV, essa organização de mundo começa a apresentar algumas fissuras. Um tempo marcado por crises em todos os setores da vida, que trouxe novos modos de experimentar a realidade. Pode ser considerado um momento de transição. Essa representação de força e potência eclesiástica vai se desconstruindo, mesmo com toda grandeza das catedrais e toda pompa na realização dos atos litúrgicos, a doença afetava tanto os clérigos mais eminentes, os nobres com mais posses, bem como o povo camponês. A sociedade estamental se dá conta de que existe um ponto em comum a todos, a vulnerabilidade estava definitivamente em todos os segmentos daquela sociedade.

Aqui pode ser de grande valia nos atentarmos para o curso ministrado por Tillich em 1955, A História do Pensamento Cristão. Ele nos dá uma chave de leitura para interpretarmos a Idade Média, sinalizando como problema básico da época, "o da realidade transcendental, manifesta e materializada numa instituição particular, numa sociedade sagrada específica, dirigindo a cultura e interpretando a natureza (2000, p. 145)." O que estava em jogo era um modelo de visão sobre a sociedade, a igreja tentando manter sua influência, e o pensamento teológico e filosófico gerava certa estabilidade a partir do encontro entre a fé e a razão.

Um pouco adiante na mesma obra, Tillich ressalta três atitudes cognitivas ou teológicas que marcam o período: escolasticismo, misticismo e biblicismo (2000, p. 146). Onde de maneira sintetizada temos: escolasticismo, a teologia da época; misticismo, a piedade pessoal experimentada; e, biblicismo, constante crítica, a partir da tradição bíblica (2000, p. 148)." Esse encontro das atitudes cognitivas ou teológicas nos permitem visualizar ainda que de maneira breve o modo como o pensamento medieval antes desse tempo difícil no século XIV se estruturava.

Era uma concepção de razão com certo status de harmonia, regulada pela autoridade e pela tradição da Igreja, credo ut intelligam, creio para entender. A vida era direcionada a partir de um viés dogmático, como existiam as leis naturais, a tradição e a autoridade eram tidas como naturais na regulação sociocultural. O modo de organização de mundo ao que parece estava correlacionado ao pensamento teológico. 
A questão dos sacramentos tinha uma importância capital no mundo medieval, para Tillich "o problema da Idade Média era o problema do mundo (sociedade e natureza) onde o divino se fazia presente por meio das formas sacramentais $(2000$, p. 163). Havia uma força na presença sacramental no medievo, qual conceito de sacramento norteava a vida espiritual naquele momento?

É um sinal visível, sensível, instituído por Deus para ser um remédio no qual sob formas materiais o poder de Deus age de maneira oculta. As ideias básicas são estas: instituição divina, sinal visível, remédio. [...] A vida inteira se passava sob os efeitos dos sacramentos. O batismo removia o pecado original; a eucaristia, os veniais; a confissão, os mortais; a extrema-unção, o que restava ainda de pecaminoso antes da morte; a confirmação levava as pessoas a lutar pela igreja; a ordenação fazia o clero; e o matrimônio leva o homem e a mulher ao desenvolvimento de sua vocação natural. Entretanto, a missa situava-se acima de todos (TILLICH, 2000, p. 165).

Esse modo de experimentar o mundo, onde a razão era guiada pela fé, com esse grau de estabilidade direcionado pela igreja, passa por uma profunda transição. E como uma hipótese provocativa, penso que o caos que vai se instaurando pelo século XIV põe abaixo esse edifício hierárquico eclesiástico que organizava a vida.

Em momentos de crise coletiva as representações que sinalizam uma ordem entram em colapso. Há uma sensação de vazio, porque parece que os símbolos de estabilidade são destituídos dos seus significados, e surge um movimento de transformação da realidade dada. A angústia passa a ser a fonte originária das ações, o plano reflexivo é tomado por estratégias de reinvenção de categorias que ajudam a compreender quais são as necessidades existenciais e os meios de amenizar esse vazio.

$\mathrm{Na}$ literatura temos prova disso, Boccaccio (1313 - 1375) em sua obra Decameron, escreve a partir do contexto da angústia em decorrência da peste, e tenta inventar um mundo alternativo ao mundo do sofrimento. Sem desconsiderar o que acontecia na dura realidade, em suas linhas o escritor italiano constrói outro mundo possível, imerso em seu tempo.

Graciosas senhoras, quanto mais penso cá comigo e contemplo como são as senhoras naturalmente piedosas, mais concluo que esta obra lhes 
parecerá austera e pesada no princípio, assim como o é a dolorosa lembrança da última peste, com que ela se inicia, para todos os que a viram ou que de algum outro modo souberam de seus estragos. Mas não quero que isso as assuste e impeça de prosseguir, como se, lendo, houvessem de estar sempre entre suspiros e lágrimas. Este horripilante início não deve ser diferente do que é para o caminhante a montanha acidentada e íngreme, atrás da qual se encontre uma planície belíssima e amena, que lhe parecerá tanto mais agradável quanto maior tiver sido o padecimento da subida e da descida. E, assim como os confins da alegria são ocupados pela dor, as misérias têm seus limites no contentamento que sobrevém (2013, p. 21).

É interessante observar que no anúncio do que seria seu texto, Boccaccio sinaliza os limites da situação difícil que ele chama de miséria. Não nos cabe aqui uma análise de teoria literária do Decameron, mas temos nessas páginas alguns elementos culturais importantes para nosso objetivo no presente artigo, que é tentar visualizar o quanto de teologia há na cultura e o quanto de cultura há na teologia, como eixos de reflexão sobre a dinâmica da fé tanto na peste do século XIV quanto na pandemia em 2020, 2021.

Boccaccio não está preocupado em falar das coisas religiosas sobre o período, mas nas entrelinhas de suas inquietações elas acabam como que por lapsos aparecendo em formas de fragmentos, ele descreve algumas cenas que elucidam as tensões espirituais experimentadas no cotidiano daqueles dias difíceis,

Tive, entre outras, a seguinte experiência, coisa vista com meus próprios olhos, como há pouco disse: um dia tendo os farrapos de um pobre homem morto da doença sido jogados na via pública, dois porcos se aproximaram deles e, conforme é seu costume, primeiro os fuçaram e depois os tomaram entre os dentes para sacudi-los; em pouco tempo, como se tivessem tomado veneno, após algumas contorções ambos caíram mortos sobre os trapos que em má hora haviam puxado (2013, p. 23).

Há nessas linhas um tom de dramaticidade, porque como se não bastasse a doença em si dizimando as vidas, se constrói um conjunto de cenas em que à dor da perda é somada a dor do abandono, do desamparo, onde a dignidade não tem condições de ser preservada.

Me fez lembrar, dialogando com uma imagem que a mídia mostrou em 2020, da cidade de Guayaquil no Equador, por conta do colapso 
do sistema funerário, onde não se tinha condições de providenciar o sepultamento de todos naquele momento, alguns corpos ficaram espalhados pelas ruas. ${ }^{1}$

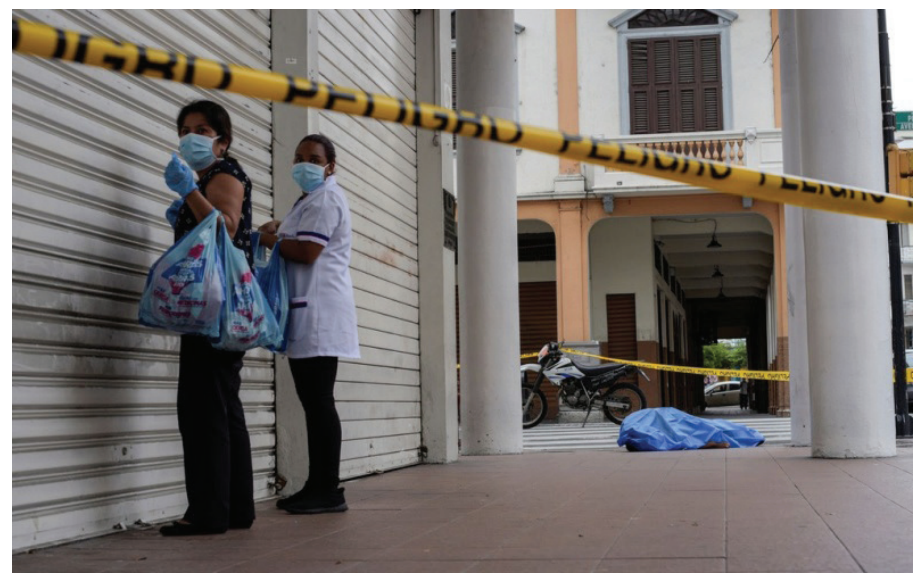

Aqui está o momento de pensarmos em uma correlação (breve) entre alguns aspectos da transformação teológico-cultural pelos idos do século XIV e a experiência que atravessamos na contemporaneidade. Levando em consideração algumas respostas que a teologia naquele tempo trouxe em um contexto de vulnerabilidade coletiva, ocasionado por uma doença terrível que levou tantas vidas num mesmo espaço de tempo.

A partir dessa correlação, surge a pergunta: o que a teologia de Tillich teria como recursos para atravessarmos nossa atual situação? Como cuidar teologicamente da dor espiritual diante de tantas histórias tristes de perdas e sentimentos de impotência?

\section{Cuidados com a dor espiritual no contexto pandêmico}

Assim como podemos falar em fraturas na cosmovisão teológico-filosófica no século XIV, em transição de uma estrutura de pensamento aparentemente ordenado, para uma crise de fé e questionamentos da ordem dada, A covid-19 trouxe profundos impactos no tocante às questões espirituais em 2020/2021.

1 https://g1.globo.com/mundo/noticia/2020/04/01/mortos-em-casa-e-cadaveres-nas-ruas-o-colapso-funerario-causado-pelo-coronavirus-no-equador.ghtml (Acessado 26/09/2021, às $9 h)$. 
Nesta parte do artigo tentarei sinalizar alguns recursos teológicos utilizados nos cuidados espirituais em minha atuação na capelania hospitalar em um hospital privado na cidade do Rio de Janeiro.

O contexto que atravessamos, que ainda não cessou (escrevo essa parte do texto no dia 28 de setembro de 2021), é um momento onde alguns conceitos da teologia tillichiana aparecem como possibilidade de cuidados espirituais em tempos de crise coletiva, essa teologia que se faz a partir da mundanidade da vida.

Talvez seja significativo mencionar aqui que na $1^{\text {a }}$ Guerra Mundial Paul Tillich atuou como capelão. Essa é uma passagem interessante porque nos provoca uma questão a respeito do lugar do teólogo em situações limite. O que pode um teólogo, com seus saberes, suas vivências e leituras, em termos de um fazer, em situações de destituição de símbolos que de alguma maneira geram segurança? Em meio a catástrofes coletivas, quando se buscam explicações por todos os lados, qual a contribuição de um teólogo?

Um olhar para a obra de Tillich, que atuou como teólogo nas trincheiras (e também viu de perto a ascensão do totalitarismo na Alemanha) pode nos ajudar na construção de um plano de cuidados espirituais em situações de tanto desamparo.

Pensar sobre a dor espiritual nessas situações de coletividade, chegando nas individualidades, nos traz algumas atitudes que reforçam o significado da fé como possibilidade de acolhimento do caos. Estamos falando de uma estrada nebulosa, e a teologia talvez nos ajude na construção de um tempo de silêncio.

Inicialmente, antes de tentar descrever o esboço de um conceito sobre o que podemos encontrar em Tillich sobre dor espiritual, vamos tentar entender o que ele pensa como dimensão ontológica, ainda que de maneira breve. "A questão ontológica é a seguinte: o que é o ser em si? (2005, p. 173).” O próprio Tillich nos alerta que essa não é a questão central que deve ocupar o teólogo. Deve fazer parte sim dos seus percursos reflexivos, "a arena da discussão ontológica não é a arena teológica, embora o teólogo deva estar familiarizado com ela (2005, p. 174)." Ele ainda enumera os quatro níveis de conceitos ontológicos - que podem servir de base para nossa reflexão teológica sobre o ser: (2005, p. 174) - (1) a estrutura ontológica básica; (2) os elementos que 
constituem a estrutura ontológica; (3) as características do ser, que são as condições da existência; (4) as categorias do ser e do conhecimento.

Esses níveis ontológicos, ao que parece no sistema tillichiano, estruturam a questão sobre Deus, que estão implícitas no ser. Na medida em que se desenvolvem os argumentos relacionados ao ser, de modo correlato, ele sinaliza os modos de compreensão sobre Deus. É como se em seu sistema ele atualizasse algo que Feuerbach (1804 - 1872) já apontava em meados do século XIX.

Feuerbach propusera uma inversão, onde o que se chamava de teologia, seria na verdade uma antropologia. Feuerbach, em suas Preleções Sobre a Essência da Religião, descreve suas percepções sobre a teologia: "agora chego às minhas obras que contêm o objeto e o tema destas preleções: minha doutrina, religião, filosofia ou como quiserdes chamar. Esta minha doutrina é simplesmente: teologia é antropologia (1989, p. 23 - grifo meu)."

A compreensão do ser humano proposta por Tillich, longe de ser um elemento determinante sobre o conhecimento a respeito de Deus, em uma estrutura rígida (como se as categorias humanas fossem uma espécie de prisão do conhecimento divino), considera o caráter de transcendência e mistério. Sem uma dogmática inexoravelmente vazia de um significado substancial, como alguns modelos de teologia mais conservadores.

Com sua teologia que transita nos limites, a partir, sobretudo, da correlação, Tillich encontra um lugar de equilíbrio, entre a radicalidade expressa em Feuerbach, de um lado, e, do outro, o fundamentalismo, expresso na teologia conservadora. Com a passagem a seguir, temos condições de vislumbrar, ainda que de modo breve, como Tillich oferece uma saída em seu sistema para uma compreensão antropológica, sem ir por um caminho de polarização, mas mantendo o diálogo: “o ser humano experimenta a si mesmo como possuindo um mundo ao qual pertence (2005, p. 179)." Aqui temos um olhar para o ser humano que rompe com uma espécie de determinismo fatalista - naquela imagem de Deus como um soberano - em uma relação hierárquica de Criador e criatura (o que em uma estrutura religiosa é bem interessante para a manutenção de poderes), e uma total desconsideração sobre as crenças 
e seus lugares de acolhimento ao mistério. Há um equilíbrio, que só quem transita nos limites consegue visualizar.

Tillich não restringe a(s) pergunta(s) sobre Deus nos limites do ser humano, somente em suas possibilidades de categorização (desde a mitologia - a poesia - a filosofia - a ciência - etc.). Não é possível tratar das questões últimas - sem tratar do ser humano. A pergunta pelo infinito faz parte de um lapso do infinito que habita os humanos. Um pouco antes da última passagem citada, Tillich escreve, "todo ser participa na estrutura do ser, mas só o ser humano está imediatamente consciente desta estrutura (2005, p. 178)."

Surge um problema aqui: o que seria essa consciência de estar na estrutura do ser?

O ser humano ocupa uma posição proeminente na ontologia, não como um objeto excepcional entre outros objetos, mas como o ser que formula a pergunta ontológica e em cuja autoconsciência se pode encontrar a resposta ontológica. [...] O ser humano é capaz de dar uma resposta à questão ontológica porque experimenta direta e imediatamente a estrutura do ser e de seus elementos (2005, p. 178).

Pensar nessa estrutura de consciência (sobre a estrutura do ser) a partir das colocações de Tillich, nos leva a questionar o que é a participação do ser no mundo e a presença do mundo no ser. Talvez o "experimentar direta e imediatamente" a estrutura do ser tenha a ver com o sentir. Na medida em que o ser humano se sente no mundo, sente o mundo em si, vivenciando e tecendo suas histórias. Essa experimentação ocorre a partir de um 'eu'.

O ser humano é um eu completamente desenvolvido e plenamente centrado. Ele 'possui' a si mesmo na forma de autoconsciência. Ele tem um eu profundo. Ser um eu significa estar separado de alguma maneira de tudo mais, ter a tudo mais diante de si mesmo, ser capaz de olhá-lo e de agir sobre ele. Ao mesmo tempo, porém, este indivíduo está consciente de que pertence àquilo para o qual olha. $\mathrm{O}$ eu está 'nele' (2005, p. 179).

Uma das questões mais desafiadoras que a pandemia da covid-19 nos trouxe foi exatamente a desintegração da estabilidade desse 'eu'. De repente fomos lançados de modo abrupto e coletivo em um contexto de vida permeado pelo medo e pela insegurança. No avanço das 
transmissões, os óbitos se multiplicaram exponencialmente. Famílias perdendo entes queridos, por vezes mais de um.

Penso que parte da compreensão desse eu no mundo de que Tillich fala tem a ver com um mundo estruturado, onde uma rotina é organizada - trabalho, estudo, convivência, etc. Podemos pensar, então, no contexto da dor espiritual no atual contexto que enfrentamos em duas dimensões: primeiro a partir de uma desconfiguração coletiva, onde o mundo organizado é forçado a mudanças em um curtíssimo espaço de tempo, o que envolve todos os setores da sociedade (economia, educação, saúde, política, religião). E, também podem ser percebidos os efeitos dessas mudanças nas singularidades de cada indivíduo.

Como poderíamos conceituar a dor espiritual a partir dessa situação? Fazendo uma correlação com o que mencionamos acima, sobre a peste bubônica e o quanto o mundo de então (século XIV) passa por um processo de desconstrução, diante da morte de tantas pessoas ao mesmo tempo, onde a impotência humana diante dos limites é explicitada. Sobretudo, pensando que a Filosofia e Teologia da época tinham sistemas estáveis que de certo modo ordenavam a visão de mundo e direcionavam o modo como as pessoas experimentavam o mundo.

De repente, todo poder divino e o poder da igreja são desafiados pelo limite extremo que a peste causava. Sacerdotes, nobres e camponeses estavam em uma mesma situação. Teólogos, filósofos e médicos estavam em um ponto de inflexão existencial, por não conseguirem de imediato respostas suficientes para dar conta das dores das perdas. Perdas de vidas e perdas de um mundo ordenado.

Assim como essa experiência tão intensa, que nos serve aqui de base para a reflexão, a covid-19 coloca as fragilidades de nosso sistema de mundo expostas. Com todo aparato científico, com tantos laboratórios e especialistas com tantas informações espalhados pelo mundo, como humanidade somos desafiados a ter que lidar com ausência de respostas às nossas grandes questões humanas, que Tillich chama de questões últimas.

Em minha atuação como teólogo e capelão no contexto hospitalar, me recordo de conversas com companheiros médicos e médicas, enfermeiros e enfermeiras, fisioterapeutas, psicólogos e psicólogas - e um sentimento em comum a todos nós: a ausência de respostas, ausência de 
parâmetros sobre como cuidar dos doentes de modo a salvar suas vidas. E alguns me perguntavam de modo atônito e sincero: onde está Deus no meio dessa situação toda? Como podemos 'ter fé' em um contexto catastrófico desses? Isso para falar do ponto de vista das perguntas dos profissionais.

Quanto aos pacientes, era nítida a situação de desespero, pois, para além dos seus pensamentos e sentimentos e fé, em seus corpos estavam os sintomas. E os que ainda estavam lúcidos no centro de terapia intensiva tinham sempre um pedido em comum: segura a minha mão. Não era pedido de oração, talvez pela impessoalidade ocasionada pela utilização dos equipamentos de proteção individual. O grande desafio junto à urgência em salvar vidas, era a urgência em construir acolhimento, a urgência em dar as mãos, e mesmo não sabendo o que iria acontecer. Tentar acolher sempre, no entanto, havia um interdito de uma ética do desespero que impossibilitava dizer: vai ficar tudo bem.

A teologia de Tillich - que é uma das principais bases teóricas que tenho como instrumento de minha atuação na capelania hospitalar - aponta para determinados insights que contribuem na tentativa de elaboração sobre o que pretendemos definir (ainda que de maneira provisória) como dor espiritual (falando aqui no contexto coletivo).

Se acima falamos sobre uma possível compreensão do ser em Tillich, agora vamos avançar e pensar sobre o ser dado às impermanências em relação ao mundo e à Deus. Para Tillich "é a finitude do ser que nos conduz à questão de Deus (2005, p. 176)." O que seria aqui a finitude, e qual seria a questão de Deus para onde a finitude nos conduz?

Para começar a tratar dessa questão, falando ainda a partir da experiência coletiva, que sinalizamos como a primeira dimensão da dor espiritual no contexto da pandemia. A desintegração do mundo dado. Ao falar sobre o 'eu' autoconsciente, que experimenta o mundo, que tem o mundo em si e se tem no mundo em que habita, Tillich assinala que "todo eu tem um ambiente em que vive, e o eu profundo tem um mundo em que vive. Todos os seres têm um ambiente que é seu ambiente. [...] O ambiente e o eu se determinam mutuamente (2005, p. $179,180)$." O ambiente onde a vida acontece em sua cotidianidade é desestruturado na pandemia. Somos lançados em nossas próprias casas, sem podermos sair. As ruas vazias, os comércios em sua maioria 
fechados, há uma profunda alteração na dinâmica da vida. A cultura tal como dada é destituída de sua normalidade.

Os canais de televisão sem poder também ter suas normalidades num primeiro momento se voltam para algumas transmissões antigas, sejam eventos esportivos marcantes, sejam novelas ou shows, uma busca à memória como tentativa de amenizar as inseguranças do presente-futuro, como se a dimensão histórica naquele período fosse um refúgio.

Houve uma aceleração no comércio digital, o que era uma tendência passa a ser uma das principais maneiras das compras acontecerem. O capitalismo enquanto sistema (sem querer aqui discutir de forma ampla o conceito de capitalismo em suas complexidades) se reinventa em cada situação. E depois de certo momento começa um movimento onde as artes ocupam também as plataformas digitais - teatro, música, exposições, a vida acontece na tela do computador, das smart tv's e smartphones. A educação também entra nesse movimento, com aulas e cursos sendo reinventados para modalidade à distância.

As reconfigurações do mundo se acelerando, e alguns rituais importantes na vida das pessoas começam a ocorrer online. Desafiando os dogmas e doutrinas, ou seja, a situação de calamidade força novos modos de habitar o(s) ambiente(s), o mundo. E a dor espiritual do ponto de vista coletivo - está nessa nostalgia, ou melancolia, uma espécie de despedida de um mundo confortável, que cede (à força) lugar para outro que não se sabia ao certo como seria. No fundo a gente nunca sabe o que vem pela frente, mas num quadro de maior estabilidade, as probabilidades funcionam de maneira a deixar-nos mais tranquilos.

Acho interessante partilhar aqui uma passagem do pensador Erich Fromm (1900 - 1980), publicada nos EUA em 1956 com o título The Sane Society - traduzido no Brasil em 1959, como A Psicanálise da Sociedade Contemporânea - onde o autor fala quase que em tom profético sobre a quebra dos modelos culturais que guiam a vida das pessoas.

Suponhamos que, em nossa cultura ocidental, os cinemas, as emissoras de rádio, as televisoras e os acontecimentos esportivos deixem de existir por apenas quatro semanas. Fechados esses principais canais de fuga, quais seriam as consequências para as criaturas, reduzidas repentinamente aos seus próprios recursos? Não tenho dúvida alguma quanto a que mesmo nesse curto período, ocorressem milhares de perturbações nervosas, e 
muitos milhares mais de criaturas fossem lançadas em um estado de ansiedade aguda que não seria diferente do quadro diagnosticado clinicamente como neurose. Se o paliativo contra o defeito socialmente modelado fosse retirado, a doença manifesta e prontamente se revelaria (1959, p. 30, 31).

Um dos aspectos centrais ao pensar na dor espiritual na dimensão coletiva é esse reconhecimento dos limites do nosso mundo, ou ambiente construído como esse lugar de segurança, onde a vida é 'levada'. E nessa ruptura com as seguranças oferecidas, os humanos são lançados a si mesmos e nas suas questões. Ir ao shopping, ir ao bar, ir a um evento esportivo, ir a uma exposição, ir a qualquer lugar, se tornou uma impossibilidade por questões sanitárias.

Surge o 'ter-que-ir-a-si-mesmo, 'dividir o ambiente consigo mesmo', e toda gama de questões que cada ser carrega em si. Não se trata de um movimento espontâneo, mas com todas as inquietações que um contexto de pandemia traz. Continua Erich Fromm,

Fiz esta experiência com várias classes de estudantes universitários: foi-lhes pedido que imaginassem que ficariam durante três dias sozinhos em seus quartos, sem rádio, sem literatura derivativa, embora supridos de 'boa' literatura, de alimentação normal e outros confortos físicos. Foi-lhes pedido que imaginassem qual seria a sua reação a essa experiência. A reação de aproximadamente 90 por cento de cada grupo variou desde a sensação de forte pânico à de uma experiência excessivamente desagradável que poderia ser vencida por várias horas de sono, vários tipos de pequenas atividades e uma espera ansiosa pelo fim desse período. Apenas uma pequena minoria julgou que se sentiriam à vontade, gozando o período em que estariam entregues a si mesmos (1959, p. 31).

O não poder sair e experimentar o ambiente em sua normalidade pode ser considerado como um foco de dor coletiva. Nas entrelinhas do confinamento estava a realidade de que o mundo habitado e experimentado tem seus limites. Como se imaginar o mundo construído onde somos tão apegados fosse uma ficção, pois em dados momentos a sensação era de um mundo distante?

Ter que se dar conta dessas limitações em termos da estrutura do mundo, desorganizou uma estrutura ontológica estável. Ser lançado no abismo e ter que enfrentar ou ser confrontado com aquilo que 
se é em essência, na sociedade do consumo, do entretenimento, foi também um dos focos de dor espiritual. Levará bastante tempo para darmos conta de elaborar reflexões. O caráter provisório do nosso mundo enquanto sistema social nos fez perceber o caráter provisório que é nosso sistema existencial.

A dimensão espiritual tem a ver com modos de conexão, não com garantias de estabilidade. Mas para além de estabilidades prometidas, cuidar da dor espiritual na dimensão coletiva é um acolhimento do caos, um acolhimento e legitimação das situações desesperadoras. É preciso avançar e transcender os discursos de fé que sinalizam ilusões. A espiritualidade não tem a ver com mágica, especialmente em um contexto coletivo. Atuar como teólogo no centro de terapia intensiva nos momentos críticos da pandemia me colocou diante de um desafio (que já era comum quando se tratava de enfrentamento de situações críticas de outros tipos de comorbidades), o pensar o lugar da espiritualidade, a religião e a fé - como sofrimentos que ultrapassavam a dimensão individual, e que desestabilizavam o modo de crer das pessoas de modo coletivo, essa foi uma novidade, a presença dessa dor coletiva, dor cultural.

Um paciente que chegou ao hospital com parte significativa dos pulmões comprometidos, junto com a esposa, ela estava em uma situação menos grave naquele momento. Ele foi para o centro de terapia intensiva, ela ficou na enfermaria. Com o passar dos dias ele evoluiu para uma melhora, ela teve uma piora considerável, a ponto de precisar de respiração artificial em ventilação mecânica. Após alguns dias o quadro da paciente se deteriora, e infelizmente ela vem a óbito. Por uma ironia dolorosa do destino isso ocorreu no dia em que seu esposo estava de alta para retornar para casa. Cada paciente que vencia a covid-19 era uma celebração, especialmente os que passaram pelo centro de terapia intensiva, era como se naqueles pacientes todos recebessem alta, celebrávamos a vida naqueles momentos. No entanto, para essa família, um momento de celebração, era um tempo de comunicação de uma má notícia. Comunicar ao esposo e ao filho que sua esposa e mãe havia falecido naquela manhã. Acompanhando a equipe médica no acolhimento, o esposo olha para mim com um semblante que penso que nunca vou esquecer, e pergunta: 
- "Nós sempre acreditamos em Deus, o servimos com amor em nossa paróquia (uma família católica apostólica romana) - no meio dessas dores todas - eu pergunto: Deus fugiu? A misericórdia d'Ele não existe de modo que possa amenizar as dores de tanta gente que como eu sofre a impotência desse momento? Eu queria respostas.'

Essa questão me tocou de forma última, porque talvez não no momento em que foi feita, mas nas ressonâncias do passar dos dias, estava implícita ali em meio à ausência de respostas a partir do silêncio de Deus, uma preocupação com a dor coletiva, como se de algum modo o sagrado perdesse força como aquilo que tivera como significado.

E aqui, está o ponto central do que queremos pensar a respeito dessa dimensão da dor espiritual: há uma quebra das representações do que dá uma sensação de segurança, as autoridades internacionais e nacionais em algum momento estiveram sem conseguir oferecer respostas. $\mathrm{O}$ isolamento social foi a medida mais segura, e como Erich Fromm na década de 1950 fez aquele experimento conforme citado acima, percebeu como a quebra da rotina social traz uma sensação de impotência e se torna fonte de desespero coletivo.

Como cuidar dessa dor espiritual coletiva? Como a teologia pode contribuir no enfrentamento de uma situação de vazio crônico diante dessa ausência de uma vida social comum? Como descobrir, ou desvelar o lugar onde encontrar Deus em um momento como esse? $\mathrm{Na}$ obra Teologia da Cultura podemos perceber em Tillich alguns insights que nos ajudam a pensar na dimensão coletiva da fé, e como podemos acolher essas questões, sem a pretensão de dar respostas prontas, mas aprimorando o modo de acolhimento.

A teologia nesse lugar não deve se preocupar em dar respostas, porque qualquer resposta aqui soaria como uma arrogância. A teologia é o instrumento, nesse caso, que nos ajuda a acolher o vazio. Tillich escreve sobre a espiritualidade e fé que se dão na cultura, utilizando o termo religião com esse significado mais amplo. Religião nesse trecho não se trata somente de uma fé institucionalizada, com um conjunto determinado de doutrinas e ensinos, mas como uma construção humana que busca interpretar o que se entende por sagrado. 
A religião revela a profundidade da vida espiritual, encoberta, em geral, pela poeira da nossa vida cotidiana e pelo barulho do nosso trabalho secular. Dá-nos a experiência do sagrado, intangível, tremendamente inspirador, significado total e fonte de coragem suprema. Eis aí a glória do que chamamos de religião (2009, p. 45).

$\mathrm{O}$ encontro entre a teologia e a cultura nos permite identificar que as crenças, a fé, a espiritualidade, ou seja, os modos de conexão permeiam a vida social e coletiva. $\mathrm{O}$ ponto de encontro não está nas formas finais do que se crê, ou no como se crê. Mas no movimento que o ato de crer aponta. É uma espécie de olhar para o antes da crença, não o depois, como uma aspiração que conecta os indivíduos. Cito um trecho para aferirmos essa afirmação a partir das palavras do próprio Tillich.

A consciência do incondicionado não tem caráter de fé. Mas é auto evidente. A fé contém certo elemento contingente e exige risco. Combina a certeza ontológica com a incerteza a respeito de todas as coisas condicionadas e concretas. Naturalmente isso não significa que a fé seja o mesmo que a crença em algo dono de maior ou menor grau de probabilidade. $\mathrm{O}$ risco da fé não quer dizer a aceitação de asserções a respeito de Deus, do ser humano e do mundo, incapazes de verificação, que talvez possam ser comprovadas no futuro. O risco da fé baseia-se no fato de que o elemento incondicional pode se tornar questão de preocupação suprema somente se aparecer de forma concreta. Pode ser visto em símbolos mitológicos purificados e racionalizados, como Deus retratado como ser supremo e pessoal, além de muitos outros conceitos teológicos tradicionais. Pode surgir em atividades rituais e sacramentais para os seguidores de religiões autoritárias e sacerdotais. Pode ainda aparecer em fórmulas e comportamentos especiais que expressem o inefável, como se vê no misticismo. Manifesta-se nas exigências proféticas e políticas em favor da justiça social quando se tornam preocupações supremas tanto religiosas como seculares. Ocorre também na devoção honesta e absoluta dos que se dedicam à verdade científica. Além disso, aparece no universalismo da ideia clássica de personalidade e na atitude estoica (antiga e moderna) de superação das vicissitudes da existência. Em todos esses casos, trata-se de um risco existencial, no qual o significado e a realização de nossas vidas estão em jogo, e não mero julgamento teórico aberto, a ser refutado mais cedo ou mais tarde (2009, p. 66).

O lugar da teologia nessa situação limite, de desintegração dos símbolos de crença e fé, por conta de uma dor coletiva, em que se trata de maneira honesta a respeito de certa impotência dos deuses, não é 
ofertar segurança, pois essa não existe, estamos tratando a fé como risco que assumimos, o que ultrapassa os horizontes de polarização entre o fato: Deus existe ou não existe? Como podemos provar?

A teologia como parte do tratamento dessa dor espiritual coletiva, contribui refinando os questionamentos. Descondicionando as perguntas de seu habitat dogmático, e lançando a fé nas possibilidades da existência, que por conta do caos encontra-se abalada em meio a tantas perdas, lágrimas e inseguranças. Uma teologia que auxilia a abraçar o caos.

Tillich sinaliza que nessa perspectiva cultural das expressões religiosas, temos de um lado os teólogos que defendem uma revelação do ponto de vista dogmático em uma tensão com os críticos que tentam invalidar o lugar da religião, num embate eterno que não leva a nenhuma solução aparente. É preciso estar além das polarizações, uma teologia do não lugar, centrada na história de cada ser. Uma teologia que não se pretende pronta, mas que se refaz a partir de cada nova pergunta, porque é atravessada pelas existências (e ausências). Quando se trata da relação entre a cultura e a questão do incondicional e do inefável, falando a partir de um lugar onde a sociedade encontra-se enclausurada em suas casas (sem saber ao certo como será, como se a ficção científica se tornasse a realidade), é bem nesse lugar de indeterminação, onde as impermanências são escancaradas, que somos convidados a ultrapassar essa tentativa de defender ou refutar o lugar da fé, pois não se trata desse dualismo. É preciso lidar com as questões teológicas do modo como elas se expressam na existência. Tanto o fundamentalismo religioso, quanto os críticos da religião disputam por algo que nesse momento não tem significado substancial. Como assinala Tillich, "o perigo de todas as expressões concretas do elemento incondicional, tanto religiosas, quanto seculares, é sua elevação ao nível do incondicional, sejam símbolos, instituições ou movimentos, absolutizando-os (2009, p. 67)."

A resposta que surge como analgesia para essa dor de falta de referências, que compõe essa quebra de símbolos de crença em que a sociedade fora arremedada, é o silêncio. Sinalizo o silêncio teológico como o espaço onde o sofrimento é acolhido em sua plenitude. Qualquer esboço de respostas, seja dogmática, seja crítica, é uma invasão aos territórios desconhecidos no coração humano, que tem mais a ver, talvez, com quem está na posição de cuidador (que quer experimentar 
suas sentenças como verdadeiras e provar ou refutar o incondicional) ao que está sendo cuidado (esse sim precisa ser acolhido - e não receber provas da presença ou não presença do incondicionado).

Cuidar da dor espiritual do ponto de vista teológico tem sido no contexto da pandemia um exercício de orações onde as respostas são as mãos dadas, a presença silenciosa, onde as lágrimas são totalmente retóricas. Na quebra de símbolos com significados sociais, na transição de modos de vida de maneira aguda como a que a sociedade enfrenta nesse momento, talvez o silêncio, o abraçar a impotência, seja o alívio, e juntos com Jesus, de modo coletivo gritarmos: Deus nosso, Deus nosso, por que nos desamparaste?

Por lidar com o mistério e com a ausência, a teologia contribui na legitimação da visão de mundo sobre o risco que é viver, tanto na coletividade, quanto na individualidade. A teologia, nesse caso, pode ser considerada como um tipo de subversão das certezas prontas. É um modo de propor um auto-re-encontro com o sagrado, no sentido do lugar último da existência, rompendo a velha questão do aquém-além. É a transfiguração do etéreo (sem deixar de acolhê-lo) no instante, uma imersão no agora com plenitude de presença, um abraçar a emergência do vazio.

Agora vamos analisar os desdobramentos da dor espiritual na dimensão individual. Aqui retomo a questão mencionada no início dessa parte sobre a ontologia como ponto de partida para pensar a questão de Deus. É sobre o ser, ou o ser entendido como um 'eu' que iremos tratar agora.

A teologia e filosofia de Kierkegaard (1813 - 1855) será utilizada aqui como um ponto de base para falarmos da dor do 'eu' no contexto da pandemia. Dito por Tillich (1999) - Kierkeggard "portava consigo durante a vida toda certa disposição melancólica (p. 177).” O pensador dinamarquês traz um novo olhar, crítico, a partir da tentativa de Hegel (1770 - 1831) de construir uma síntese universal e uma lógica que daria conta de explicar as questões da vida pelo viés filosófico.

A lógica para Kierkegaard transcendia o esquema de tese, antítese e síntese. Talvez nas entrelinhas do sistema hegeliano habitassem os problemas aos quais Kierkegaard versava. Ele antecipa o existencialismo tal como temos hoje, segundo Tillich comentando a obra de Kierkegaard: 
O indivíduo coloca-se diante de Deus, solitário, e o processo do mundo não pode libertá-lo da tremenda responsabilidade em face a situação em que vive. Disse repetidamente que a última realidade é o indivíduo com a sua capacidade de fazer escolhas, indivíduo esse que deve decidir livremente pelo bem ou pelo mal. [...] Qual é a razão dessa experiência de solidão? Deve-se à finidade humana da alienação. Não se trata da finidade que se identifica com o infinito, mas da finidade separada, que se ergue sobre si mesma no indivíduo. Enquanto o princípio da identidade se mantinha, era possível superar a ansiedade do infinito, de ter que morrer, pela experiência da união com o infinito. Mas essa resposta não era possível para Kierkegaard. Assim, procurou mostrar porque vivemos em ansiedade e desespero. Vivemos em ansiedade porque somos finitos e em desespero porque vivemos essa ansiedade num estado finito de solidão (1999, p. 178).

É a partir da existência que o ser humano tem um lapso de compreensão sobre as questões últimas. No percurso da ansiedade, e no desespero, o ser humano percebe-se no deserto, dado à solidão. Há uma obstrução às potencialidades do ser nesse momento, pois não se consegue visualizar saídas. Se o ser humano experimenta o mundo a partir de si mesmo, se é no existir que o ser vai se tecendo com tessituras múltiplas que o estruturam e desestruturam num mesmo movimento, é importante reconhecer que não há uma lógica que direciona os acontecimentos, há o caos. Entender e acolher essa ansiedade e desespero é tarefa que a teologia ajuda a fazer.

É no conflito entre o que se quer ser e o que é possível ser que a vida se desdobra. O ser humano se constrói e se reconstrói em paradoxo, não há uma lógica transcendente que oferta segurança e explicação para o sofrimento, há o sofrimento. No próprio sofrimento experimentado, não no intelecto ou nas ideias, mas na existência, é que se buscam as respostas. Há um infinito que habita o finito, quase que uma impossibilidade ou um absurdo. E é exatamente nesse lugar que encontramos em Kierkegaard uma possibilidade de cuidados com a dor do 'eu' ou a dor espiritual.

Pois o desespero leva o ser humano a um esvaziamento, e nesse ponto se inicia o mistério da transcendência, ele sai de si em outras direções para além de si. O salto no vazio como movimento de transcendência a partir da autotranscendência. Como pensar o acolhimento dessa ansiedade e desespero como caminho para os cuidados com o 
espiritual na dimensão do indivíduo? Voltaremos à Teologia Sistemática para tentarmos esboçar uma analgesia tillichiana.

$\mathrm{Na}$ abertura da segunda parte de sua Teologia sistemática na alínea A ele escreve sobre a estrutura ontológica básica, o eu e o mundo, conforme trouxemos algumas passagens acima. Na alínea B Tillich vai traçar os elementos ontológicos. E na alínea $\mathbf{C}$ o foco será o ser e a finitude. E por fim, na alínea D, o ser e a pergunta por Deus, Tillich ensina sobre a finitude humana e a questão de Deus. É importante notar que as reflexões a respeito da pergunta por Deus, para Tillich, digo mais uma vez, se iniciam no ser. Ou seja, o ser é o ponto de partida em direção ao infinito. "Todas as estruturas da finitude obrigam o ser finito a transcender-se a si mesmo e, exatamente por essa razão, a tomar consciência de si mesmo como finito (2005, p. 199)."

Eu queria pensar em uma possibilidade de descrição da dor espiritual nesse espaço entre a tomada de consciência de si mesmo como finito e a possibilidade de transcendência. Para Tillich "a finitude na consciência é angústia. [...] A angústia é a autoconsciência do eu finito como finito (2005, p. 200)." Talvez seja no percurso entre o ser e o não-ser que essa consciência ou autoconsciência da finitude aparece como angústia. Saber-se um ser dotado de organização no espaço-tempo, com alguns anseios por permanência, e de repente, saber-se na iminência de um não-ser.

Uma das saídas que podem auxiliar nesse processo de dor espiritual, que é essa iminência consciente do não-ser - também chamada de angústia - é seu acolhimento num primeiro momento. Somente acolhendo esse nada que se aproxima consegue-se enfrentar as questões que se desdobram dessas perguntas últimas que transitam pelos limites do ser. É uma espécie de sensação de ameaça do nada. O nada é aqui relacionado ao absurdo, ausência de forma, de pensamento, talvez o lugar onde Deus habitava antes da criação - "a terra era sem forma e vazia" - como enfrentar essa situação?

Essa angústia suscitada pela existência temporal só é suportável porque é contrabalançada por uma coragem que afirma a temporalidade. Sem esta coragem, o ser humano se renderia ao caráter aniquilador do tempo; ele renunciaria a ter um presente. Mas o ser humano afirma o momento presente, embora analiticamente lhe pareça irreal, e o defende contra a 
angústia que a transitoriedade gera nele. Ele afirma o presente graças à coragem ontológica que é tão autêntica quanto sua angústia diante do processo do tempo. Esta coragem é efetiva no ser humano, pois este é capaz de prever seu fim. Por isso, o ser humano necessita de maior coragem para assumir sua angústia. [...] O ser humano não pode evitar a questão do fundamento último de sua coragem ontológica (2005, p. 203).

No mesmo lugar onde nasce a angústia, na indeterminação, no espaço entre o ser e o não-ser, surge um horizonte de coragem para acolher a vida em suas potencialidades e se desenvolver. No acolhimento do vazio e no experimentar a angústia está o que Tillich irá chamar de coragem de ser.

Ser implica o risco do não-ser, na verdade mais que um risco, um fato. A teologia para além de esperança soteriológica, no além, pode contribuir na existência humana, no aquém. Uma das maneiras que a teologia pode ajudar no enfrentamento da dor espiritual, é quando ela legitima a dúvida, o medo, a angústia, tudo o que representa o caráter da vulnerabilidade humana. Não há aqui uma dissimulação de deuses ou Deus cheios de poder e com o controle e governo do mundo.

Surgem outras possibilidades para a espiritualidade e a para a fé, que ainda não estão prontas, mas que certamente nos trarão outras perspectivas de compreensão na medida em que formos aprendendo a lidar com os novos desafios em suas complexidades.

\section{Considerações finais}

Ao tentarmos correlacionar a experiência da peste bubônica e a covid-19, em temporalidades tão distintas, modos de perceber o mundo tão diferentes, algumas questões se atravessam. Nos idos do século XIV diante do horror do adoecimento a estrutura de mundo de então começara a ruir. Era um mundo teológico e filosófico bem estruturado, o mundo das catedrais góticas que apontavam os caminhos para o céu. De repente todos estavam sujeitados ao medo e ao sentimento de impotência. A experiência hodierna da covid-19 também colocou os limites do mundo teológico e filosófico, as catedrais de nosso tempo (os shoppings) e lugares badalados ficaram esvaziados por um bom tempo. E do mesmo modo que no limiar da Idade Média, ficamos sujeitados ao medo e ao sentimento de impotência. 
Um novo mundo nascia, na verdade chama-se para fins didáticos de Renascimento aquele mundo. Pensando em nosso contexto, a questão que fica em aberto para uma construção coletiva, mas também individual, é que tipo de renascimento conseguiremos dar conta de tecer? Nos redescobrirmos como humanos para além do capital, mas cultivando valores como a generosidade, o afeto, a gratidão, a partilha. Tanto os poderosos quanto os mais pobres, na Idade Média e hoje, foram assolados por perdas de gente querida, o caminho para o não-ser, falando de maneira mais específica a dimensão tanatológica - que nesses episódios coloca todos num lugar muito próximo - pode potencializar um tipo de soteriologia diferente. Que é o acolhimento aos processos de humanização e uma ética de alteridade.

As doenças como desarmonia, como evidência da fragilidade dos recursos humanos, tal como nesses dois períodos aparecerem de maneira coletiva e individual, remetem a um lugar da espiritualidade que nos humaniza. Pensar em uma 'desteologização' da teologia, um 'desempoderamento' dos divinos todo-poderosos. Na própria humanidade, lançada em si mesma, nas suas dores, habitam os anseios pelo sagrado. Que pode ser entendido como cura - em contraposição à doença como desarmonia - uma reintegração da harmonia. Embora não seja possível essa plenitude aqui por conta dos riscos que a vida oferece, a vida como em uma unidade de terapia intensiva, é possível estar em busca. E talvez estar em movimento, assumir o devir, inclusive nas compreensões sobre o sagrado e o infinito a partir do ser limitado, que nos oferecem um refrigério em meio ao caos. Antes de ofertar respostas contundentes, de manuais, a teologia nos ajuda a acolher as ambiguidades.

\section{Referências}

BOCCACCIO, G. Decameron. São Paulo: L\&PM, 2013.

FEUERBACH, L. Preleções Sobre a Essência da Religião. Campinas: Papirus, 1989.

FROMM, E. Psicanálise da Sociedade Contemporânea. Rio de Janeiro: Zahar, 1959.

GILSON, E. A Filosofia na Idade Média. São Paulo: Martins Fontes, 1995. GONZÁLES, J. L. História Ilustrada do Cristianismo: a era dos mártires até a era dos sonhos frustrados. São Paulo: Vida Nova, 2011. 
LE GOFF, J. O Deus da Idade Média: conversas com Jean-Luc Pouthier. Rio de Janeiro: Civilização Brasileira, 2010.

LINDBERG, C. As Reformas na Europa. São Leopoldo, RS: Sinodal, 2001. TILliCH, P. Perspectivas da Teologia Protestante nos Séculos XIX e XX. São Paulo: Aste, 1999.

Teologia Sistemática. São Leopoldo: Sinodal, 2005.

Teologia da Cultura. São Paulo: Fonte Editorial, 2009.

Submetido em: 1-11-2021

Aceito em: 19-1-2022 